\title{
Deleterious MnSOD signals lead to abnormal breast cell proliferation by radiation and estrogen exposure
}

\author{
CARLOS ECHIBURÚ-CHAU ${ }^{1}$, DEBASISH ROY ${ }^{2}$ and GLORIA M. CALAF ${ }^{1,2}$ \\ ${ }^{1}$ Instituto de Alta Investigación, Universidad de Tarapacá, Arica, Chile; ${ }^{2}$ Department of Natural Sciences, \\ Hostos College of the City University of New York; ${ }^{3}$ Center for Radiological Research, \\ Columbia University Medical Center, New York, NY, USA
}

Received November 22, 2010; Accepted January 27, 2011

DOI: $10.3892 /$ ijo.2011.978

\begin{abstract}
Manganese superoxide dismutase (MnSOD) seems to have a pivotal role in mantaining the normal phenotype by suppressing cell growth through blocking the entrance of quiescent cells into the cell cycle. MnSOD protein expression has been shown to be dysregulated in malignant cells. A well-established experimental breast epithelial cell cancer model was used to observe the relationship in the presence or absence of such protein and the phenotype of the cells. This model was derived from the spontaneously immortalized breast epithelial cell line MCF-10F, which was transformed with estrogen and radiation. The results of this study showed that deleterious expression of MnSOD enhanced the malignant phenotype demonstrated by cell cycle protein expression changes. Thus, the malignant cell line, called Alpha5, which had high levels of MnSOD protein expression, maintained a similar phenotype to the normal cell line MCF-10F. The cell cycle arrest observed in $G_{1}$ phase of the Alpha5 cell line was induced by 16 protein expression which has been shown to inhibit the Cyclin D1/CdK4 complex explaining such arrest. It can be concluded from these studies that SOD expression, played a critical role in free radical detoxification and it is directly correlated with the cell cycle, defining one of the most important characteristics of tumor cells, namely cell growth and proliferation. These findings are in agreement with the hypothesis that MnSOD plays a role as a possible tumor suppressor gene. Furthermore, this work is a contribution to understanding the possible changes that occur in $\alpha$-particle irradiated cells, sensitized with estrogen, due to the presence of superoxide dismutase scavenger that could have significant implications in the design of clinical radiotherapeutic protocols.
\end{abstract}

Correspondence to: Dr Gloria M. Calaf, Instituto de Alta Investigación, Universidad de Tarapacá, Calle Antofagasta \#1520, Arica, Chile

E-mail: gmc24@columbia.edu

Key words: Manganese superoxide dismutase, hydrogen peroxide, ROS, estrogen, radiation, breast cells, cell growth

\section{Introduction}

Intracellular redox status in cells is modulated by antioxidants that remove the excess of reactive oxygen species (ROS, e.g., superoxide and hydrogen peroxide) allowing a continuous balance (1). In a normal state, ROS are produced by reduction of oxygen in the mitochondrial electron transport chain and enzymatic reactions (1). In this case, ROS at low concentrations perform essential metabolic functions in regulating signal transduction pathways and transcription factors (2).

The ROS scavenger is removed by superoxide dismutase (SOD) that converts superoxide $\left(\mathrm{O}_{2}{ }^{--}\right)$to hydrogen peroxide $\left(\mathrm{H}_{2} \mathrm{O}_{2}\right)$, then catalase and glutathione peroxidases lead the transformation from hydrogen peroxide to water $\left(\mathrm{H}_{2} \mathrm{O}\right)$ and oxygen $\left(\mathrm{O}_{2}\right)$ (3). In mammalian cells there are three isoforms of this enzyme such as the MnSOD, located in the mitochondrial matrix, the extracellular superoxide dismutase (EcSOD) in the plasma membrane and the extracellular space, $\mathrm{Cu} / \mathrm{Zn}$ superoxide dismutase (CuZnSOD) is located in the cytosol, nucleus, peroxisome, and intermembrane space of mitochondria (4-7). Since mitochondria are the major source of cellular ROS, MnSOD appear to be one of the most important to analyze from these SOD isoforms (3).

ROS have been considered to be toxic byproducts causing damage to cellular macromolecules. Intensive studies have shown possible causative role of ROS on tumor initiation and transformation (8-13). In this sense, ROS such as hydrogen peroxide and superoxide have been reported to induce changes at the level of proto-oncogene expression $(14,15)$. On the other hand, there is evidence that ROS, at low levels, regulate multiple cellular processes, including proliferation (16-19). For example, cell cycle phase transitions could be regulated by cellular redox environment (20-22).

The cell cycle is a highly coordinated event which is monitored by checkpoints through different steps such as entry, progression through the cell cycle and transition to the quiescent growth that are essential to prevent aberrant proliferation (23). Transition from quiescence $\left(\mathrm{G}_{0}\right)$ to proliferative growth $\left(G_{1}\right.$ to $S$ to $G_{2}$ and $\left.M\right)$ involves the sequential activation of cyclin-dependent kinase activities $(24,25)$. Furthermore, MnSOD has a direct participation in the cell growth, for example, there is evidence that MnSOD activity regulates the cell growth in mouse and human fibroblasts $(3,26,27)$. 
Studies have shown that MnSOD maintains normal growth capacity of the normal human skin fibroblasts cultured in vitro through the upregulation of cyclin-dependent kinase inhibitor (p16) protein levels (21). MnSOD activity has been shown to have a close relation to cyclin D1 and cyclin B1 protein levels (3). The increase of this antioxidant and the levels of ROS suppress cyclin D1 accumulation, and inhibit the transition from quiescent to the proliferative cycle (1).

Oberley and Oberley (28) were the first to consider the idea that MnSOD might be a tumor suppressor gene based in its low and high presence in undiferentiated stem and differentiated cells, respectively (29). These authors propose that a decrease in MnSOD activity might play a casual role in cell immortalization and transformation (1).

The protective role of MnSOD influencing pivotal proteins in the cell cycle allow to suggest that this protein is involved in malignant transformation. Therefore, the aim of this work was to analyze the role of this enzyme in breast epithelial cells and the influence of estrogen and radiation. A well-established experimental breast cancer model based on MCF-10F cell line transformed with estrogen and radiation in malignant cells was used in this study (30).

\section{Materials and methods}

Cell culture. The spontaneously immortalized breast epithelial cell line MCF-10F (ATCC, Manassas, VA), was used as a control. This cell line retains all the characteristics of normal epithelium in vitro, including anchorage-dependence, non-invasiveness and non-tumorigenicity in nude mice (31-33). To analyze the oxidative stress system the malignant counterpart from the Alpha model was used (30). From this model two cell lines were used: i) Alpha5, MCF-10F cell line irradiated with a double dose of $60 \mathrm{cGy}$ of $\alpha$-particles and treated with estrogen ( $17 \beta$-estradiol, $1 \times 10^{-8} \mathrm{M}$ ) (SigmaAldrich, St. Louis, MO) before each radiation exposure. This cell line was anchorage-independent, invasive and tumorigenic in nude mice. ii) Tumor2, derived from mammary tumors formed in nude mice after injection of the Alpha5 cells. The cell lines were cultured with Dulbecco's modified Eagle's medium (DMEM)/F-12 (1:1) supplemented with $100 \mathrm{U} / \mathrm{ml}$ penicillin, $100 \mathrm{mg} / \mathrm{ml}$ streptomycin, $2.5 \mathrm{mg} / \mathrm{ml}$ amphotericin $\mathrm{B}$ (all from Life Technologies, Grand Island, NY), $10 \mathrm{mg} / \mathrm{ml}$ insulin (Sigma-Aldrich), 5\% equine serum (Biofluids, Rockville, MD), $0.5 \mathrm{mg} / \mathrm{ml}$ hydrocortisone (Sigma) and 0.02 $\mathrm{mg} / \mathrm{ml}$ epidermal growth factor (Collaborative Research, Bedford, MA). The cells were incubated at $37^{\circ} \mathrm{C}$ with $5 \% \mathrm{CO}_{2}$ up to $70 \%$ of confluence. To determine the cell population doubling time (Dt) the cells were counted at the time of replating then 24,48 , and $72 \mathrm{~h}$ after plating. Dt was calculated from the exponential portion of the growth curve seeding $5 \times 10^{5}$ cells per $25 \mathrm{~cm}^{2}$ flask at initial time.

Cell cycle analysis. Propidium iodide staining was used for measuring by fluorescence-Activated Cell Sorting (FACS). The cells were trypsinized and fixed in $70 \%(\mathrm{v} / \mathrm{v})$ ethanol, and washed with cold PBS. To assess the DNA content the cells were incubated for $30 \mathrm{~min}$ with propidium iodide/RNase staining Buffer (BD Pharmingen ${ }^{\mathrm{TM}}$ ) covered with aluminium foil and measured using flow cytometry. Percentage of cells in each phase of the cell cycle was analyzed using BD CellQuest Pro software (Becton-Dickinson, Co.) using an ultraviolet excitation laser beam.

Measurement of $\mathrm{H}_{2} \mathrm{O}_{2}$ concentration. To determine the hydrogen peroxide level the Amplex ${ }^{\circledR}$ Red Hydrogen Peroxide/Peroxidase Assay Kit (Molecular Probes, Eugene, CA) was used. The protocol was according to the manufacturer's procedure. HRP stock solution $(10 \mathrm{U} / \mathrm{ml})$ was diluted $(0-2 \mathrm{mU} / \mathrm{ml})$ for the standard curve. A volume of $50 \mu \mathrm{l}$ was used for each reaction of individual wells of a microplate. The microplate with reactions were incubated at room temperature for $30 \mathrm{~min}$, protected from light. The absorbance was measured in a microplate reader at $\sim 560 \mathrm{~nm}$. The background was corrected for each point subtracting the value derived from the no-HRP control.

Western blot analysis. Protein was extracted by lysing cells in extraction buffer $(50 \mathrm{mM}$ Tris- $\mathrm{HCl}, \mathrm{pH} 8.0,130 \mathrm{mM} \mathrm{NaCl}$, $1 \%$ (w/v) NP-40, $1 \mathrm{mM}$ phenylmethylsulfonyl fluoride, $5 \mathrm{mM}$ $\mathrm{MgCl}_{2}$ and $1 \mathrm{mM}$ orthovanadate). The protein concentration was determined by Bicinchoninic Acid Protein Assay Kit (Sigma-Aldrich). Equivalent amounts of protein $(25 \mu \mathrm{g})$ were fractionated by electrophoresis in SDS-polyacrylamide gel. The protein was subsequently transferred to PVDF membranes with Trans-Blot ${ }^{\circledR}$ SD Semi-Dry Electrophoretic Transfer Cell (Bio-Rad, Hercules, CA, USA). Antibodies against NFкB (sc-53744), MnSOD (sc-133134), catalase (sc-58332), cyclin A (sc-751), cyclin B1 (sc-752), cyclin D1 (sc-718) and cyclin E (sc-198) (all from Santa Cruz Biotechnology, Santa Cruz, CA, USA) were applied to probe the membranes (dilution 1:5001:1000). The secondary antibodies (anti-mouse or anti-rabbit) (all from Santa Cruz Biotechnology) were conjugated to horseradish peroxidase (dilution 1:5000). Signals were detected using the ECL kit SuperSignal West Pico Chemiluminescent Substrate (Thermo Scientific, Rockford, IL, USA) according to the the company's protocol. Kodak BioMax light film (SigmaAldrich). $\beta$-actin (sc-47778) was used as loading control (dilution 1:8000), and fold change calculated relative to control.

Immunocytochemical detection. Protein expression was evaluated by peroxidase immunochemical staining (34). The cells were plated on a 4-well glass chamber slide (Nunc Inc., Naperville, IL, USA). Cells were allowed to grow at a density of $1 \times 10^{4}$ cells in $1 \mathrm{ml}$ of medium for 2-3 days until they reached $70 \%$ confluency. The cells were incubated with $1 \%(\mathrm{v} / \mathrm{v}) \mathrm{H}_{2} \mathrm{O}_{2}$ in methanol for $30 \mathrm{~min}$, in order to block endogenous peroxidase, washed twice with a buffer solution, and fixed with buffered paraformaldehyde in PBS, pH 7.4, at room temperature. Subsequently, cell cultures were then covered with normal horse serum for $30 \mathrm{~min}$ at room temperature. Cultures were then washed once and incubated with the corresponding antibodies at a 1:500 dilution overnight at $4^{\circ} \mathrm{C}$. The following antibodies were used: MnSOD (sc-133134) and catalase (sc-58332) (all from Santa Cruz Biotechnology). The protein expression in the different cell lines was determined by using the avidin-biotin-horseradish immunoperoxidase peroxidase complex (Standard ABC kit; Vector, Burlingame, CA, USA). 3,3-diaminobenzidine (DAB) (Sigma-Aldrich) was used as a chromogen. For negative controls, duplicate samples 
Table I. Primers of genes selected for differential display reverse transcriptase-PCR (DDRT-PCR) analysis.

$\begin{array}{lll}\text { Symbol } & \text { Length of product }(\mathrm{pb})^{\mathrm{a}} & \text { Primer }^{\mathrm{b}} \\ \text { Gene name } & \end{array}$

\begin{tabular}{lcc}
\hline $\begin{array}{l}\text { SOD2 } \\
\text { Manganase superoxide dismutase }\end{array}$ & 406 & $\begin{array}{l}\text { Sense: ccctggaacctcacatcaac } \\
\text { Antisense: ccttgcagtggatcctgatt }\end{array}$ \\
$\begin{array}{l}\text { CAT } \\
\text { catalase }\end{array}$ & 475 & $\begin{array}{l}\text { Sense: cgtgctgaatgaggaacaga } \\
\text { Antisense: tccaatcatccgtcaaaaca }\end{array}$ \\
$\begin{array}{l}\text { ACTB } \\
\beta \text {-actin }\end{array}$ & 569 & Sense: actacctcatgaagatcctc \\
\end{tabular}

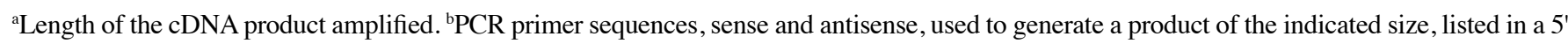
to 3 ' orientation.

were immunostained without exposure to the primary antibody or substituted with pre-immune serum.

Differential display reverse transcriptase-PCR (DDRT-PCR) assessment. Total RNA was isolated using TRIzol reagent (Invitrogen Corp., Long Island, NY). The purified RNA sample was first measured by a spectrophotometer (the ratio of absorbance reading at $260 / 280 \mathrm{~nm}>1.8$ ) and then electrophoresed on $1.5 \%(\mathrm{w} / \mathrm{v})$ denaturing formaldehyde/agarose gel to check its quality and purity. RNA ( $3 \mu \mathrm{g})$ was used for reverse transcriptase-polymerase chain reaction (RT-PCR). The first-strand cDNA was synthetized with primer oligo-(dT) to hybridize to 3'-poly-(A) tails. To confirm their similar expression in all samples human $\beta$-actin was used as a control amplifier set. Table I shows the primers of genes selected for DD-RT-PCR analyses, including the symbol, product length and type of primers of superoxide dismutase (SOD2), catalase $(C A T)$ and $\beta$-actin (ACTB) (all primers from Sigma-Aldrich). To confirm the differential expression of the 2 genes under study, different amounts of cDNA and a varied number of PCR cycles were used to generate gene-specific probes. A linear increase was observed in product generation in all cases (log-phase). Then $1 \mu \mathrm{l}$ of cDNA and 23 cycles for SOD2 and $C A T$; and 14 cycles for $A C T B$ for PCR were used. Table II shows the protocol of DD-RT-PCR analyses including the gene symbol, cycles, PCR step and temperature/time. In each PCR initial cycle of $94^{\circ} \mathrm{C}$ for 2 min was necessary to activate Taq polymerase and a final cycle of $72^{\circ} \mathrm{C}$ for 2 min was utilized to complete the amplicon produced. The PCR product was run on a $2 \%(\mathrm{w} / \mathrm{v})$ agarose gel. Differentially expressed gene-specific DNA bands were then photographed and analyzed with AdobePhotoShop software to obtain the relative grade of luminescence to calculate the fold-change of expression.

\section{Results}

Abnormal breast cell growth pattern. The doubling time (Dt) is commonly used to determine the replication time of the cell population. The Dt was 45.4, 71.2 and $26.7 \mathrm{~h}$ for MCF-10F, Alpha5 and Tumor2, respectively (Fig. 1A). These data revealed that cell growth was diminished in Alpha5 cell line in
Table II. Protocol of differential display reverse transcriptase-PCR (DDRT-PCR).

\begin{tabular}{lcll}
\hline Gene symbol & Cycles (no.) & PCR step & Temperature/time \\
\hline SOD2 & 23 & Denaturation & $94^{\circ} \mathrm{C} / 45 \mathrm{sec}$ \\
& & $\begin{array}{l}\text { Annealing } \\
\text { Extension }\end{array}$ & $53^{\circ} \mathrm{C} / 40 \mathrm{sec}$ \\
& & $72^{\circ} \mathrm{C} / 60 \mathrm{sec}$ \\
& \multirow{2}{*}{23} & Denaturation & $94^{\circ} \mathrm{C} / 30 \mathrm{sec}$ \\
CAT & & Annealing & $56^{\circ} \mathrm{C} / 30 \mathrm{sec}$ \\
& & Extension & $72^{\circ} \mathrm{C} / 30 \mathrm{sec}$ \\
& & & \\
ACTB & 14 & Denaturation & $94^{\circ} \mathrm{C} / 45 \mathrm{sec}$ \\
& & Annealing & $59^{\circ} \mathrm{C} / 40 \mathrm{sec}$ \\
& & Extension & $72^{\circ} \mathrm{C} / 60 \mathrm{sec}$ \\
\hline
\end{tabular}

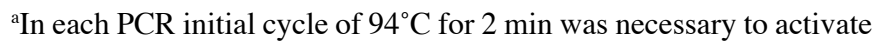
Taq polymerase and a final cycle of $72^{\circ} \mathrm{C}$ for 2 min was utilized to complete the amplicon produced.

comparison to control, supported by flow cytometry analyses, as seen in Fig. 1B. The cell cycle of Tumor 2 cell line appeared displaced toward phase $\mathrm{S}(15.83 \%)$ and $\mathrm{G}_{2} / \mathrm{M}(17.10 \%)$ in comparison to MCF-10F (S:11.55\%; $\mathrm{G}_{2} / \mathrm{M}: 14.24 \%$ ). The low number of cells encountered in $\mathrm{G}_{2} / \mathrm{M}$ phase in Alpha5 $\left(\mathrm{G}_{2} / \mathrm{M}\right.$ : $11.76 \%$ ) cell line corresponded to cells with a lower proliferative capacity than the control cell line.

Altered $\mathrm{H}_{2} \mathrm{O}_{2}$ level in breast malignant cell lines. To determine the hydrogen peroxide level is important as an indicative factor of the balance between ROS generation and antioxidant activity. Fig. $2 \mathrm{~A}$ shows the $\mathrm{H}_{2} \mathrm{O}_{2}$ concentration $(\mu \mathrm{M})$ obtained from the cell lines studied. The results indicated that the malignant Alpha5 cells had higher concentration of $\mathrm{H}_{2} \mathrm{O}_{2}$ than MCF-10F and Tumor2 cells. However, decreased amount of $\mathrm{H}_{2} \mathrm{O}_{2}$ was observed in Tumor 2 cells in comparison to the control cells. 

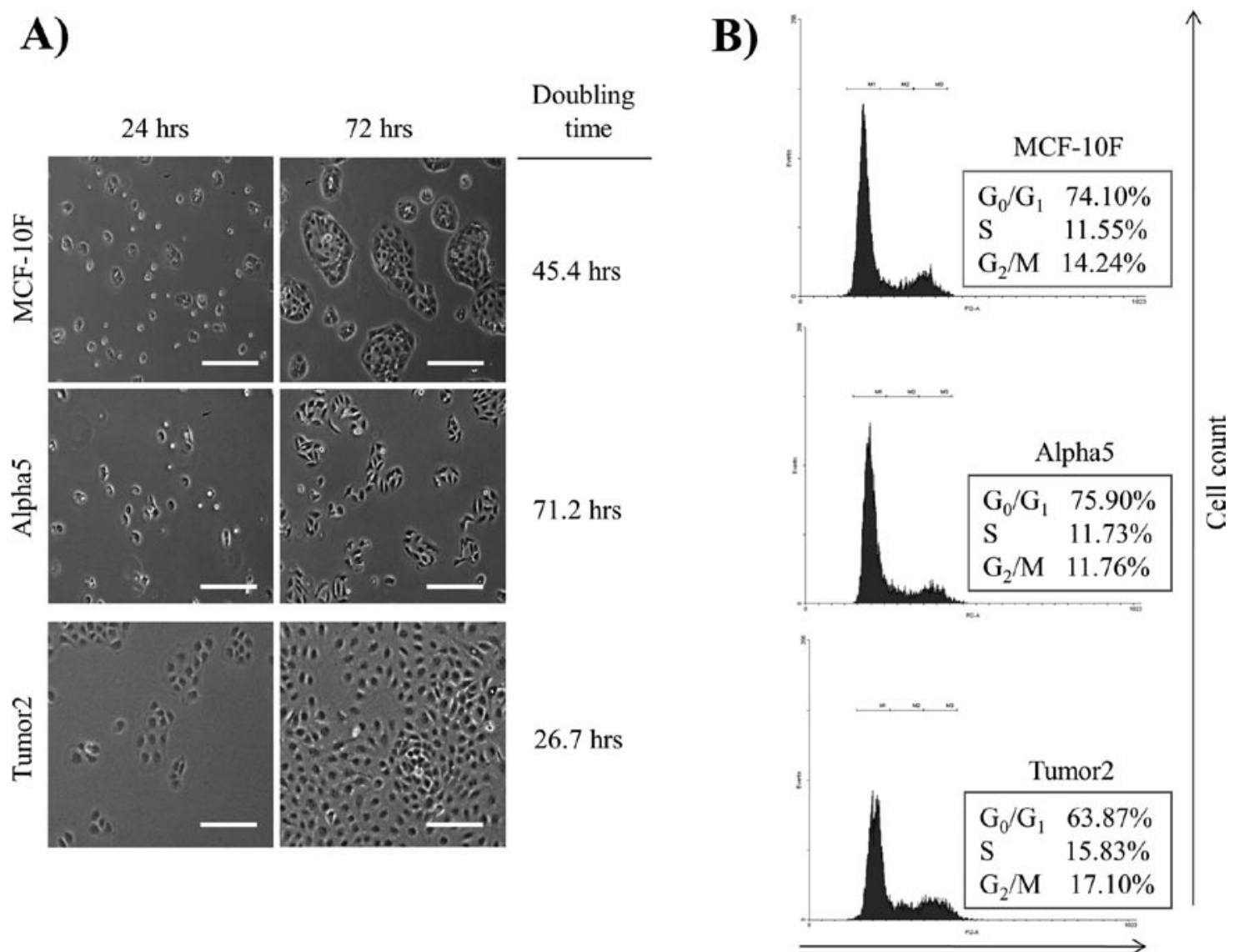

DNA content

Figure 1. Doubling time and fluorescence-activated cell sorting (FACS) analysis. (A) Representative images of cell growth 24 and $72 \mathrm{~h}$ after platting. Doubling time was calculated in logarithmic phase of MCF-10F, Alpha5 and Tumor2 cell lines. (B) Representative DNA content histograms of MCF-10F, Alpha5 and Tumor 2 cell lines. The percentage of the cells entering the specific phase of the cell cycle was determined by flow cytometric analysis of propidium iodidestained cells.

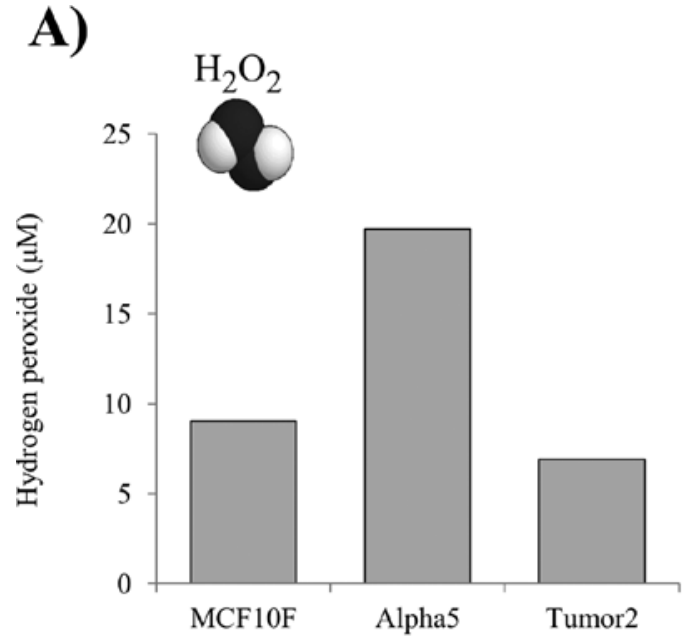

Figure 2. Hydrogen peroxide production assay and $\mathrm{NF}_{\kappa} \mathrm{B}$ protein expression (A) $\mathrm{H}_{2} \mathrm{O}_{2}$ levels were determined in MCF-10F, Alpha5 and Tunor2 cell lines by using a quantitative colorimetric assay based on horseradish peroxidecatalyzed $\mathrm{H}_{2} \mathrm{O}_{2}$ oxidation of Amplex Red. The concentration $(\mu \mathrm{M})$ was calculated by measuring the absorbance at $560 \mathrm{~nm}$ using a microplate reader. (B) The NFKB protein expression, considered as specific signaling pathway of oxidative stress, was analyzed through Western blotting. The NFKB shows two reactive bands (105 and $50 \mathrm{kDa}$ ) and $\beta$-actin was used as loading control (top panel). The intensity of the band was recorded and represented in a graph with relative grade of luminescence (bottom panel).
B)
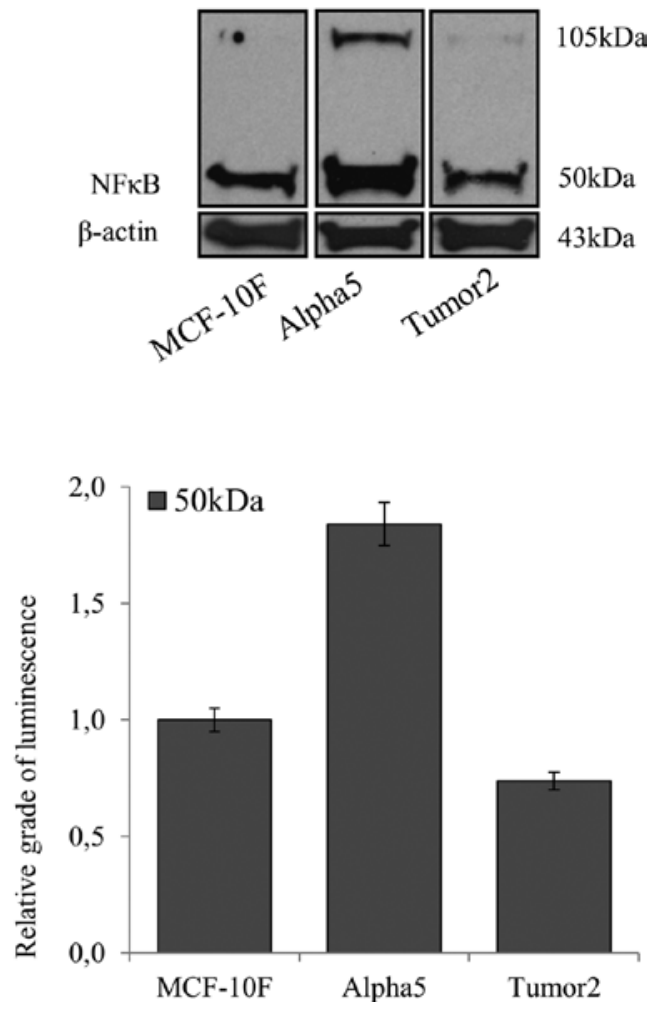
A)

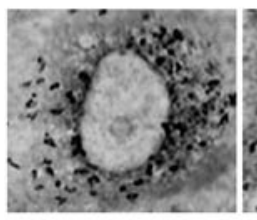

MCF-10F

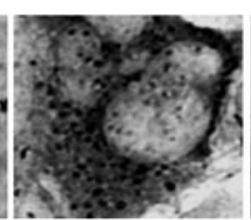

Alpha5

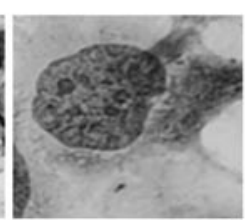

Tumor2
B)

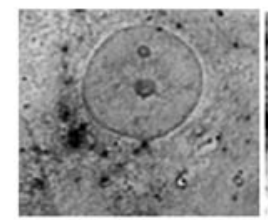

MCF-10F

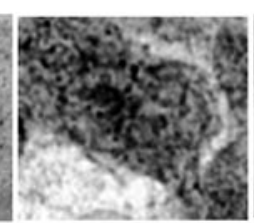

Alpha5

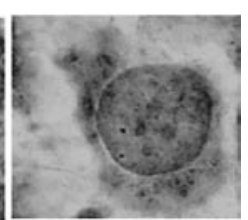

Tumor2
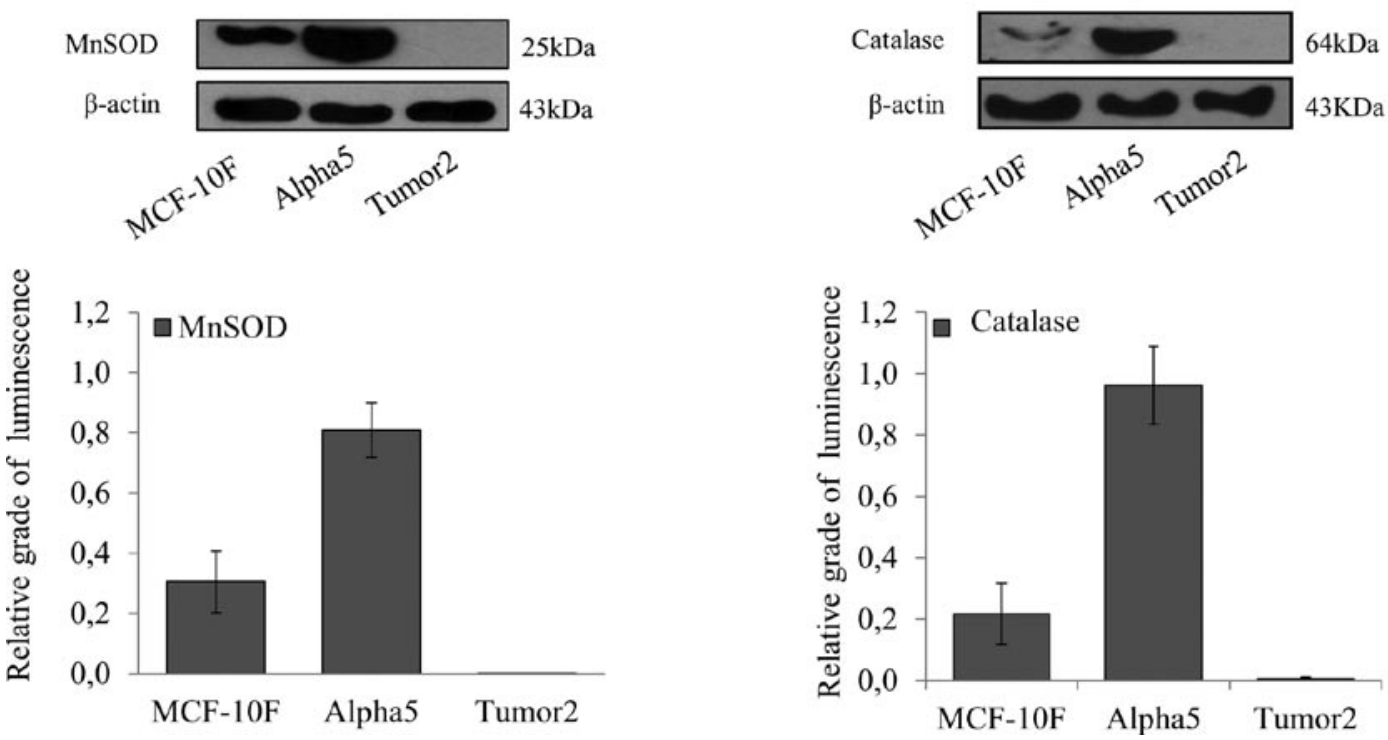

Figure 3. MnSOD and catalase protein expression. MnSOD immunodetection was assessed by: (A) immunocytochemistry (top panel) and Western blotting (middle panel) analyses in MCF-10F, Alpha5 and Tumor 2 cell lines. $\beta$-actin was used as control to correct for loading in Western blotting. The graph shows the relative grade of luminescence to assess the protein level of MnSOD (bottom panel). (B) Catalase immunodetection was assessed by: (A) immunocytochemistry (top part) and Western blot (middle panel) analyses in MCF-10F, Alpha5 and Tumor 2 cell lines. In Western blotting $\beta$-actin was used as control to correct for loading. The graph shows the relative grade of luminescence to assess the protein level of catalase (bottom panel).

Nuclear factor kappa $B(N F \kappa B)$ protein expression was directly proportional to hydrogen peroxide levels. Is has been reported that $\mathrm{NF} \kappa \mathrm{B}$ is involved in the oxidative stress pathway and is translocated from the cytoplasm into the nucleus induced by $\mathrm{H}_{2} \mathrm{O}_{2}$. The $\mathrm{NF} \kappa \mathrm{B}(50 \mathrm{kDa})$ protein level was found overexpressed in Alpha5 (1.8-fold) and downregulated in Tumor2 (0.7-fold) in comparison with MCF-10F (1.0) cell line, as seen in Fig. 2B. This is consistent with the precursor molecule of $105 \mathrm{kDa}$ which was found overexpressed in Alpha5 cells. The expression of this protein was directly proportional to hydrogen peroxide level measured in the three cell lines.

Altered MnSOD and catalase protein expression. MnSOD and catalase are two of the most important ROS scavengers. The expression of these proteins was analyzed by inmunodetection. Fig. 3A shows the MnSOD (25 kDa) protein expression surrounded the nuclei corresponding to mitochondrial localization. Alpha5 cell line presented strong inmunostaining in comparison to MCF-10F, the MnSOD expression in the Tumor 2 cell line was absent. These data were corroborated through Western blot assessment where the MnSOD level was overexpressed (2.8-fold) in Alpha5 in comparison to MCF-10F. However, the signal was not found in Tumor2 cell line at the same detection level. Fig. 3B shows catalase $(64 \mathrm{kDa})$ protein expression in MCF-10F, Alpha5 and Tumor2 cell lines. Alpha5 cell line presented a strong inmunostain in comparison to MCF-10F. Whereas, the catalase expression was absent in the Tumor 2 cell line. These data were corroborated through Western blot technique where in Alpha5 the catalase level was overexpressed (4.8-fold) in comparison to MCF-10F, and the signal disappear in Tumor 2 cells at the same detection level.

Altered SOD2 gene expression. To clarify whether the marked reduction of MnSOD and catalase protein expression observed in Tumor 2 cell line was due to a depression of SOD2 and CAT genes, differential gene expression was assessed. SOD2 gene expression was upregulated (1.4-fold) in Alpha5 cell line in comparison with MCF-10F, as seen in Fig. 4A. On the other hand, the signal in Tumor 2 cells was downregulated and almost disappeared ( 0.5 -fold). The pattern of gene and protein expression of this scavenger was directly proportional. Contrary to expectations, CAT gene expression was similar in the three cell lines and it was not correlated to protein expression level as shown in Fig. 4B.

Altered cyclins in relation to cell growth. The progress of the cells from steady state $\left(\mathrm{G}_{0}\right)$ to cell cycle initiation $\left(\mathrm{G}_{1}\right)$ depends mainly on the cyclin D family. From this family, cyclin D1 protein level is often used as indicator of cells entering the proliferative stage. Fig. 5A shows the detection of cyclin D1 


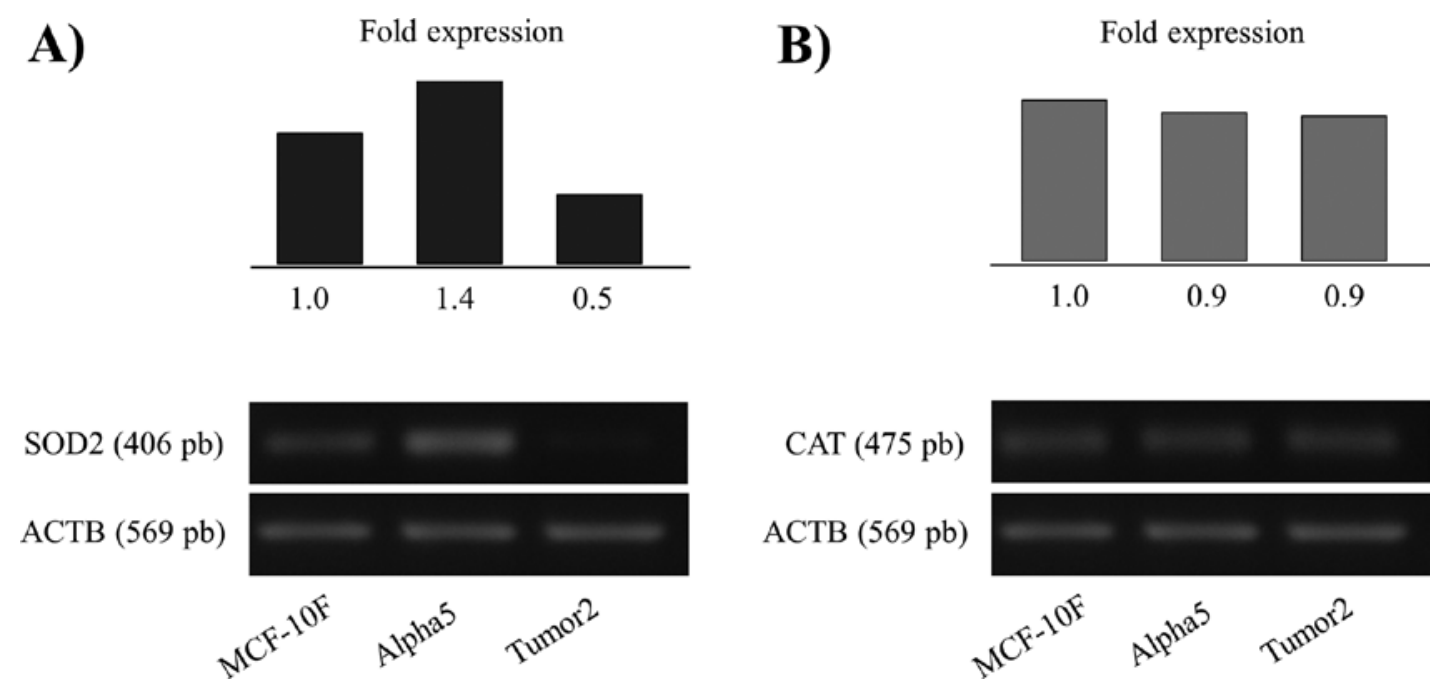

Figure 4. SOD2 and CAT DD-RT-PCR analyses. The differential expression was analyzed with DDRT-PCR technique for: (A) SOD2 and (B) CAT genes. $\beta$-actin was used as loading control. The cDNA was electrophorezed in $2 \%$ agarose gel.

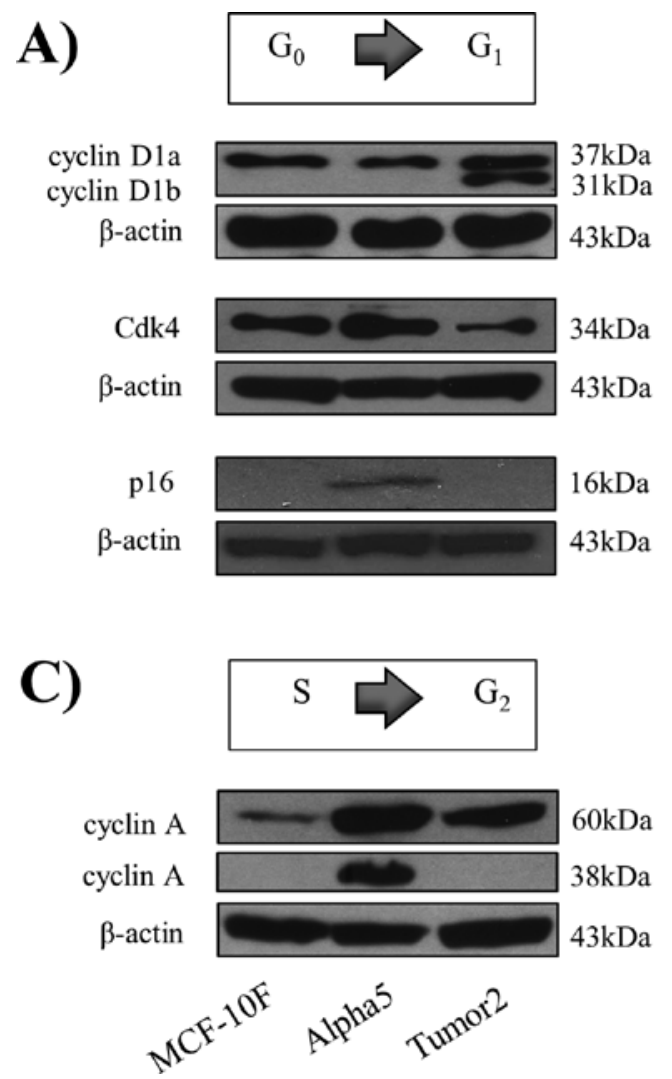

\section{B)}

cyclin E

LMW-cyclin E

$\beta$-actin
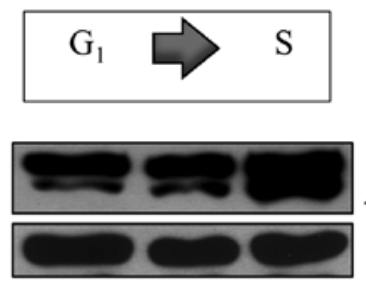

$55 \mathrm{kDa}$

$<55 \mathrm{kDa}$

$43 \mathrm{kDa}$

D)

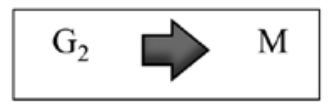

cyclin B1

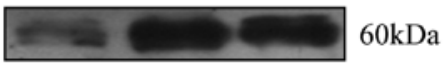

$\beta$-actin

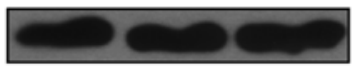

$43 \mathrm{kDa}$

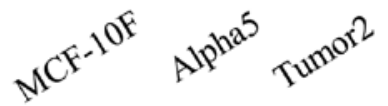

Figure 5. Expression of cell cycle-related proteins. Inmunodetection by Western blot analysis of: (A) Cyclin D1, CdK4 and p16; (B) Cyclin E; (C) Cyclin A; and (D) Cyclin B1 protein expression in MCF-10F, Alpha5 and Tumor2 cell lines. $\beta$-actin was used as loading control.

by immunoblotting. Two cyclin D1-reactive bands corresponding to cyclin D1a (37 kDa) and cyclin D1b (31 kDa) were observed in Tumor 2 cell line in contrast to $\mathrm{MCF}-10 \mathrm{~F}$ and Alpha5 where it was only possible to observe the $37 \mathrm{kDa}$ band corresponding to cyclin D1a. Contrary to expectations, the protein expression of Cdk4 (34kDa) was downregulated in Tumor2 (0.5-fold) in comparison to MCF-10F.

When the cell goes from $G_{1}$ to $S$ phase, the presence of cyclin $\mathrm{E}$ seems to be important. It is possible to observe in
Fig. 5B a cyclin E reactive bands corresponding to a low molecular weight form $(<55 \mathrm{kDa})$ that was overexpressed in Tumor2 (3.7-fold) in comparison to MCF-10F. Cyclin A is a protein present in the transition from $S$ phase to $G_{2}$. The overexpression of cyclin A (60 kDa) in Alpha5 (5.9-fold) and Tumor2 (3.3-fold) in comparison to control can be observed in Fig. 5C. A low molecular weight cyclin A-reactive band (38 $\mathrm{kDa}$ ) was observed in Alpha5 cell line. On the other hand, cyclin $B$ family is committed to $\mathrm{G}_{2}-\mathrm{M}$ transition, thus cyclin 
B1 is frequently used as indicators of cells entering into and exiting from the proliferative cycle protein. Fig. 5D shows cyclin B1 protein expression over-expressed in Alpha5 (3.5fold) and Tumor2 (3.1-fold) in comparison to MCF-10F.

\section{Discussion}

This study showed that MnSOD enzyme that plays an important role in oxidative stress also revealed a protective role through controlling the breast cell proliferation. The data demonstrated that Alpha5 and Tumor2, both malignant cell lines transformed with a combination of radiation and estrogen exposure, presented variations in pivotal proteins that determine a differential cell growth according to the presence or absence of MnSOD protein levels.

Deleterious MnSOD expression resulted in an aggressive phenotype of Tumor2 cell line leading a dysregulated growth. $\mathrm{Li}$ et al (2) showed that overexpression of the human $M n S O D$ gene in MCF-7 cells was capable of inhibiting cell proliferation both in vitro and in vivo. These data are in agreement with findings that suggest that MnSOD works as a tumor suppressor gene in human breast cancer cells. An in vivo study (35) showed in Wistar rats treated with $\alpha$-particles enhanced SOD production after $4 \mathrm{~h}$ of radiation treatment and its decay after $16 \mathrm{~h}$ of treatment. Assuming that the time of exposure to radiation is directly proportional to damage of the cells, it is possible to argue that the rats after 16 hours of exposure had certain damage that can be correlated with the loss of SOD activity. Transformation is often accompanied by lowered MnSOD activity $(8,10)$, as was observed in the Tumor 2 cell line. Other data $(13,36)$ show that increase of cellular ROS have been associated with carcinogenesis, whereas antioxidants have the capacity to prevent malignant transformation both in vitro and in vivo as occurred here in the Alpha5 cell line. On the other hand, the catalase protein expression was reduced concomitantly with diminished MnSOD expression, but this reduction seems to be a consequence of low hydrogen peroxide production. It is known that CAT expression is regulated by hydrogen peroxide production (37). The CAT mRNA level observed in this work was not correlated with the catalase protein expression level. Since the posttranscriptional events of catalase are particulary complex $(38,39)$ these findings need to be elucidated.

The expression of MnSOD is mediated by the presence of hydrogen peroxide. In other cell lines like human promyelocytic leukemia cells (HL60) relatively higher levels of $\mathrm{H}_{2} \mathrm{O}_{2}$ induced similar effects by inhibiting cell growth (8). It is recognized that cancer cells contain an elevated ROS level, specifically hydrogen peroxide as a result of oncogenic transformation (40), and also as a product of excess MnSOD activity. There are reports (41) that associate $\alpha$-particles with ROS production. It is possible that the elevated hydrogen peroxide basal content in Alpha5 cell line is due to the formation of estradiol oxidative metabolism products acting as an enhancer in this process (42).

According to other studies $(15,43,44)$, it is possible that the high concentration of hydrogen peroxde in Alpha5 induced overexpression of specific oxidative stress related gene pathways like $N F_{\kappa} B$ as well as cell cycle arrest in $G_{0} / G_{1}$ phase. It seems that $\mathrm{NF}_{\kappa} \mathrm{B}$ protein does not simply affect growth by enhancing cell cycle progression. Studies on epidermal epithelial cell and transformed cells hint at other cell specific roles. Overexpression of $\mathrm{NF \kappa B}$ in epidermal epithelial cells suppresses, rather than enhances, the cell growth. However, inhibition of $\mathrm{NF \kappa B}$ causes hyperplasia (45).

It has been demonstrated that $\mathrm{NF}_{\mathrm{K}} \mathrm{B}$ is a direct inductor of cyclin D1, a proto-oncogene responsive to mitogenic stimuli inducing $\mathrm{G}_{1} / \mathrm{S}$ phase transition of the cell cycle (46-49). $\mathrm{NF}_{\kappa} \mathrm{B}$ was overexpressed in Alpha5 in comparison to control and Tumor2. Furthermore, cyclin D1a was not affected by NFאB since it was equally expressed in the three cell lines. The cyclin D1a isoform was expressed at the same level in the three cell lines except in Tumor2 cell line that expressed also an alternative splice isoform termed Cyclin D1b. Cyclin D1b is a constitutive nuclear protein lacking exon 5 where PEST (Pro-Glu-Ser-Thr) motif and the Thr286 residue are located, which are required for the nuclear export and degradation of cyclin D1 (50). In response to mitogens, cyclin D1 is induced and dimerizes with Cdk4 $(51,52)$. Therefore, in contrast with Cyclin D1a, Cyclin D1b can cause cellular transformation and has been linked to human cancers $(50,53)$. These results can explain the abnormal growth of Tumor 2 cell line.

In the present study it was found that the cell cycle of Alpha5 cell line was suppressed in $G_{0} / G_{1}$ phase by overexpression of p16 protein. This signal was downregulated in Tumor2 cell line and this checkpoint was avoided. Several studies (54-59) have demonstrated that the suppression of p16 activity or overexpression of cyclin D1, can promote tumor development (51). The present data showed that suppression of cell growth of Alpha5 was due to possible inhibition of CdK4/Cyclin D1 complex formation by p16 protein but not by diminishing CdK4 or cyclin D1 protein expression. On the contrary, the abnormal growth of Tumor 2 cell line was due to the formation of cyclin D1b isoform, but not the overexpression of cyclin D1a protein as it occurs in tumorigenic cells. Paradoxically, CdK4 protein expression was diminished in Tumor2 cells where cell growth was stimulated.

Cyclin $\mathrm{E}$ is a key factor in the $\mathrm{G}_{1}$ checkpoint, promoting transition into $\mathrm{S}$ phase (60). Under normal conditions cyclin $\mathrm{E}$ is only present in low cellular amounts (61). Keyomarsi et al (62) have reported that this protein does not seem to be essential in $\mathrm{G}_{1} / \mathrm{S}$ transition since it has been reported that overexpression of cyclin E had no effect on TGF 33 -mediated inhibition of growth in MCF-10F cells. They also reported cyclin E overexpression in several human tumor types, which levels have been related to tumor stage and grade in breast cancer. Furthermore, it is important to consider that cyclin $\mathrm{E}$ is able to form biologically hyperactive cyclin $\mathrm{E}$ of low molecular weight (LMW-E) isoforms $(<55 \mathrm{kDa})$ that lack the normal $\mathrm{N}$-terminus and can also be overexpressed in tumor tissue $(63,64)$. Thus, the LMW-E isoforms have a more profound effect on cell cycle deregulation than full-length cyclin E (63). The present result showed that the cyclin E was expressed at the same level in the three cell lines except in Tumor 2 cell line that overexpressed LMW-E isoforms. LMW-E accumulation is tumor-specific and these isoforms have been found in multiple tumor types including breast, ovarian and colorectal cancers, and melanomas (65-68). The transgenic mice expressing LMW-E isoforms had more changes in mammary tumor development and in metastasis than transgenic mice 
with full-length cyclin E overexpressed (69-72). However, the mechanisms underlying LMW-E regulation and function remain to be clarified.

An increase of cyclin A expression is a frequent abnormality and may play an important role in the pathogenesis of both human and animal tumors (73). The present result showed that the cyclin A $(60 \mathrm{kDa})$ was overexpressed in Alpha5 and Tumor2 in comparison to MCF-10F. However, a low molecular weigth protein derived from cyclin A, called A38 (38 kDa), was only overexpressed in Alpha5 cell line, indicating the difference with Tumor 2 in the proliferative capacity. Welm et al (74) showed that truncated A38 protein product can be found in the nucleus and was able to bind and form active complexes with Cdk2.

The data presented in this work support the idea that MnSOD plays a role as a tumor suppressor gene. Furthermore, this work was a contribution for understanding the possible changes that occur under estrogen and radiation exposure. According to other data (12,75-77) increase of MnSOD protein expression by sense cDNA transfection can suppress radiationinduced neoplastic transformation. Since cell cycle checkpoints have been proposed to act as regulators of tumor sensitivity $(78,79)$, the identification of $G_{1}$ delay in $\alpha$-particle irradiated cells, sensitized with estrogen, due to presence of superoxide dismutase scavenger may have significant implications in the design of clinical radiotherapeutic protocols.

\section{Acknowledgements}

Technical assistance of Ms. Susana Alfaro Lira and Ms. Maria Pizarro Ortiz and support given by FONDECYT (\#1080482) (G.M.C.) are greatly appreciated.

\section{References}

1. Chaudhuri L, Sarsour EH, Kalen AL, Aykin-Burns N, Spitz DR and Goswami PC: Polychlorinated biphenyl induced ROS signaling delays the entry of quiescent human breast epithelial cells into the proliferative cycle. Free Radic Biol Med 49: 40-49, 2010.

2. Li JJ, Oberley LW, Fan M and Colburn NH: Inhibition of AP-1 and NF-kappaB by manganese-containing superoxide dismutase in human breast cancer cells. FASEB J 12: 1713-1723, 1998.

3. Sarsour EH, Venkataraman S, Kalen AL, Oberley LW and Goswami PC: Manganese superoxide dismutase activity regulates transitions between quiescent and proliferative growth. Aging Cell 7: 405-417, 2008.

4. Valko M, Rhodes CJ, Moncol J, Izakovic M and Mazur M: Free radicals, metals and antioxidants in oxidative stress-induced cancer. Chem Biol Interact 160: 1-40, 2006.

5. Zelko IN, Mariani TJ and Folz RJ: Superoxide dismutase multigene family: a comparison of the CuZn-SOD (SOD1), Mn-SOD (SOD2), and EC-SOD (SOD3) gene structures, evolution, and expression. Free Radic Biol Med 33: 337-349, 2002.

6. Folz RJ and Crapo JD: Extracellular superoxide dismutase (SOD3): tissue-specific expression, genomic characterization, and computerassisted sequence analysis of the human EC SOD gene. Genomics 22: 162-171, 1994.

7. McCord JM and Fridovich I: Superoxide dismutase. An enzymic function for erythrocuprein (hemocuprein). J Biol Chem 244: 6049-6055, 1969.

8. Oberley LW and Buettner GR: Role of superoxide dismutase in cancer: a review. Cancer Res 39: 1141-1149, 1979.

9. Slaga TJ, Klein-Szanto AJ, Triplett LL, Yotti LP and Trosko KE: Skin tumor-promoting activity of benzoyl peroxide, a widely used free radical-generating compound. Science 213: 1023-1025, 1981.

10. Oberley LW and Oberley TD: Role of antioxidant enzymes in cell immortalization and transformation. Mol Cell Biochem 84 147-153, 1988.
11. Bowden GT, Jaffe D and Andrews K: Biological and molecular aspects of radiation carcinogenesis in mouse skin. Radiat Res 121: 235-241, 1990.

12. St Clair DK, Wan XS, Oberley TD, Muse KE and St Clair WH: Suppression of radiation-induced neoplastic transformation by overexpression of mitochondrial superoxide dismutase. Mol Carcinog 6: 238-242, 1992.

13. Cerutti P, Ghosh R, Oya Y and Amstad P: The role of the cellular antioxidant defense in oxidant carcinogenesis. Environ Health Perspect 102 (Suppl. 10): 123-129, 1994.

14. Devary Y, Gottlieb RA, Lau LF and Karin M: Rapid and preferential activation of the c-jun gene during the mammalian UV response. Mol Cell Biol 11: 2804-2811, 1991.

15. Nose K, Shibanuma M, Kikuchi K, Kageyama H, Sakiyama S and Kuroki T: Transcriptional activation of early-response genes by hydrogen peroxide in a mouse osteoblastic cell line. Eur J Biochem 201: 99-106, 1991.

16. Burdon RH and Gill V: Cellularly generated active oxygen species and HeLa cell proliferation. Free Radic Res Commun 19: 203-213, 1993.

17. Sundaresan M, Yu ZX, Ferrans VJ, Irani K and Finkel T: Requirement for generation of $\mathrm{H}_{2} \mathrm{O}_{2}$ for platelet-derived growth factor signal transduction. Science 270: 296-299, 1995.

18. Bae YS, Kang SW, Seo MS, et al: Epidermal growth factor (EGF)-induced generation of hydrogen peroxide. Role in EGF receptor-mediated tyrosine phosphorylation. J Biol Chem 272: 217-221, 1997.

19. Irani K, Xia Y, Zweier JL, et al: Mitogenic signaling mediated by oxidants in Ras-transformed fibroblasts. Science 275: 1649-1652, 1997.

20. Goswami PC, Sheren J, Albee LD, et al: Cell cycle-coupled variation in topoisomerase IIalpha mRNA is regulated by the 3'-untranslated region. Possible role of redox-sensitive protein binding in mRNA accumulation. J Biol Chem 275: 38384-38392, 2000.

21. Sarsour EH, Agarwal M, Pandita TK, Oberley LW and Goswami PC: Manganese superoxide dismutase protects the proliferative capacity of confluent normal human fibroblasts. J Biol Chem 280: 18033-18041, 2005.

22. Menon SG and Goswami PC: A redox cycle within the cell cycle: ring in the old with the new. Oncogene 26: 1101-1109, 2007.

23. Malumbres $\mathrm{M}$ and Barbacid $\mathrm{M}$ : Cell cycle, CDKs and cancer: a changing paradigm. Nat Rev Cancer 9: 153-166, 2009.

24. Sherr CJ: Mammalian G1 cyclins. Cell 73: 1059-1065, 1993.

25. Grana X and Reddy EP: Cell cycle control in mammalian cells: role of cyclins, cyclin-dependent kinases (CDKs), growth suppressor genes and cyclin-dependent kinase inhibitors (CKIs). Oncogene 11: 211-219, 1995.

26. Menon SG, Sarsour EH, Spitz DR, et al: Redox regulation of the G1 to $S$ phase transition in the mouse embryo fibroblast cell cycle. Cancer Res 63: 2109-2117, 2003.

27. Menon SG, Sarsour EH, Kalen AL, et al: Superoxide signaling mediates N-acetyl-L-cysteine-induced G1 arrest: regulatory role of cyclin D1 and manganese superoxide dismutase. Cancer Res 67: 6392-6399, 2007.

28. Oberley LW and Oberley TD: The role of superoxide dismutase and gene amplification in carcinogenesis. J Theor Biol 106: 403-422, 1984.

29. Oberley TD, Oberley LW, Slattery AF, Lauchner LJ and Elwell JH: Immunohistochemical localization of antioxidant enzymes in adult Syrian hamster tissues and during kidney development. Am J Pathol 137: 199-214, 1990.

30. Calaf GM and Hei TK: Establishment of a radiation- and estrogeninduced breast cancer model. Carcinogenesis 21: 769-776, 2000.

31. Soule HD, Maloney TM, Wolman SR, et al: Isolation and characterization of a spontaneously immortalized human breast epithelial cell line, MCF-10. Cancer Res 50: 6075-6086, 1990.

32. Tait L, Soule HD and Russo J: Ultrastructural and immunocytochemical characterization of an immortalized human breast epithelial cell line, MCF-10. Cancer Res 50: 6087-6094, 1990.

33. Calaf G, Russo J, Tait L, Estrad S and Alvarado ME: Morphological phenotypes in neoplastic progression of human breast epithelial cells. J Submicrosc Cytol Pathol 32: 83-96, 2000.

34. Calaf GM, Roy D and Hei TK: Immunochemical analysis of protein expression in breast epithelial cells transformed by estrogens and high linear energy transfer (LET) radiation. Histochem Cell Biol 124: 261-274, 2005.

35. Ma J, Yonehara H, Ikebuchi M and Aoyama T: Effect of radon exposure on superoxide dismutase (SOD) activity in rats. J Radiat Res (Tokyo) 37: 12-19, 1996. 
36. Cerutti PA: Prooxidant states and tumor promotion. Science 227: 375-381, 1985.

37. Mates JM, Perez-Gomez C and Nunez De Castro I: Antioxidant enzymes and human diseases. Clin Biochem 32: 595-603, 1999.

38. Singh I, Kremser K, Ghosh B, Singh AK and Pai S: Abnormality in translational regulation of catalase expression in disorders of peroxisomal biogenesis. J Neurochem 67: 2373-2378, 1996.

39. Pedraza-Chaverri J, Granados-Silvestre MD, Medina-Campos ON Maldonado PD, Olivares-Corichi IM and Ibarra-Rubio ME: Post-transcriptional control of catalase expression in garlic-treated rats. Mol Cell Biochem 216: 9-19, 2001.

40. Behrend L, Henderson G and Zwacka RM: Reactive oxygen species in oncogenic transformation. Biochem Soc Trans 31: $1441-1444,2003$

41. Narayanan PK, Goodwin EH and Lehnert BE: Alpha particles initiate biological production of superoxide anions and hydrogen peroxide in human cells. Cancer Res 57: 3963-3971, 1997.

42. Schallreuter KU, Chiuchiarelli G, Cemeli E, et al: Estrogens can contribute to hydrogen peroxide generation and quinonemediated DNA damage in peripheral blood lymphocytes from patients with vitiligo. J Invest Dermatol 126: 1036-1042, 2006.

43. Chua PJ, Yip GW and Bay BH: Cell cycle arrest induced by hydrogen peroxide is associated with modulation of oxidative stress related genes in breast cancer cells. Exp Biol Med 234: 1086-1094, 2009.

44. Denhardt DT: Oncogene-initiated aberrant signaling engenders the metastatic phenotype: synergistic transcription factor interactions are targets for cancer therapy. Crit Rev Oncog 7: 261-291, 1996.

45. Seitz CS, Lin Q, Deng H and Khavari PA: Alterations in NF-kappaB function in transgenic epithelial tissue demonstrate a growth inhibitory role for NF-kappaB. Proc Natl Acad Sci USA 95: 2307-2312, 1998.

46. Guttridge DC, Albanese C, Reuther JY, Pestell RG and Baldwin AS Jr: NF-kappaB controls cell growth and differentiation through transcriptional regulation of cyclin D1. Mol Cell Biol 19: 5785-5799, 1999.

47. Hinz M, Krappmann D, Eichten A, Heder A, Scheidereit C and Strauss M: NF-kappaB function in growth control: regulation of cyclin D1 expression and G0/G1-to-S-phase transition. Mol Cell Biol 19: 2690-2698, 1999.

48. Westerheide SD, Mayo MW, Anest V, Hanson JL and Baldwin AS Jr: The putative oncoprotein Bcl-3 induces cyclin D1 to stimulate G(1) transition. Mol Cell Biol 21: 8428-8436, 2001.

49. Alao JP, Gamble SC, Stavropoulou AV, et al: The cyclin D1 proto-oncogene is sequestered in the cytoplasm of mammalian cancer cell lines. Mol Cancer 5: 7, 2006.

50. Solomon DA, Wang Y, Fox SR, et al: Cyclin D1 splice variants. Differential effects on localization, RB phosphorylation, and cellular transformation. J Biol Chem 278: 30339-30347, 2003.

51. Weinberg RA: The retinoblastoma protein and cell cycle control. Cell 81: 323-330, 1995.

52. Beijersbergen RL and Bernards R: Cell cycle regulation by the retinoblastoma family of growth inhibitory proteins. Biochim Biophys Acta 1287: 103-120, 1996.

53. Knudsen KE: The cyclin D1b splice variant: an old oncogene learns new tricks. Cell Div 1: 15, 2006.

54. Aagaard L, Lukas J, Bartkova J, Kjerulff AA, Strauss M and Bartek J: Aberrations of $16^{\text {Ink4 }}$ and retinoblastoma tumoursuppressor genes occur in distinct sub-sets of human cancer cell lines. Int J Cancer 61: 115-120, 1995.

55. Bartkova J, Lukas J, Strauss M and Bartek J: The PRAD-1/ cyclin D1 oncogene product accumulates aberrantly in a subset of colorectal carcinomas. Int J Cancer 58: 568-573, 1994.

56. Jiang W, Zhang YJ, Kahn SM, et al: Altered expression of the cyclin D1 and retinoblastoma genes in human esophageal cancer. Proc Natl Acad Sci USA 90: 9026-9030, 1993.

57. Otterson GA, Kratzke RA, Coxon A, Kim YW and Kaye FJ: Absence of p16 ${ }^{\mathrm{INK} 4}$ protein is restricted to the subset of lung cancer lines that retains wild-type RB. Oncogene 9: 3375-3378, 1994.

58. Schauer IE, Siriwardana S, Langan TA and Sclafani RA: Cyclin D1 overexpression vs. retinoblastoma inactivation: implications for growth control evasion in non-small cell and small cell lung cancer. Proc Natl Acad Sci USA 91: 7827-7831, 1994
59. Shapiro GI, Edwards CD, Kobzik L, et al: Reciprocal Rb inactivation and $\mathrm{p}^{16^{\mathrm{INK}} 4}$ expression in primary lung cancers and cell lines. Cancer Res 55: 505-509, 1995.

60. Draetta GF: Mammalian G1 cyclins. Curr Opin Cell Biol 6: 842-846, 1994

61. Sherr CJ: D-type cyclins. Trends Biochem Sci 20: 187-190, 1995.

62. Keyomarsi K, O'Leary N, Molnar G, Lees E, Fingert HJ and Pardee AB: Cyclin E, a potential prognostic marker for breast cancer. Cancer Res 54: 380-385, 1994.

63. Porter DC, Zhang N, Danes C, et al: Tumor-specific proteolytic processing of cyclin E generates hyperactive lower-molecularweight forms. Mol Cell Biol 21: 6254-6269, 2001.

64. Lindahl T, Landberg G, Ahlgren J, et al: Overexpression of cyclin $\mathrm{E}$ protein is associated with specific mutation types in the p53 gene and poor survival in human breast cancer. Carcinogenesis 25: 375-380, 2004.

65. Keyomarsi K and Pardee AB: Redundant cyclin overexpression and gene amplification in breast cancer cells. Proc Natl Acad Sci USA 90: 1112-1116, 1993

66. Bales E, Mills L, Milam N, et al: The low molecular weight cyclin $\mathrm{E}$ isoforms augment angiogenesis and metastasis of human melanoma cells in vivo. Cancer Res 65: 692-697, 2005.

67. Bedrosian I, Lu KH, Verschraegen C and Keyomarsi K: Cyclin E deregulation alters the biologic properties of ovarian cancer cells. Oncogene 23: 2648-2657, 2004.

68. Davidson B, Skrede M, Silins I, Shih Ie M, Trope CG and Florenes VA: Low-molecular weight forms of cyclin E differentiate ovarian carcinoma from cells of mesothelial origin and are associated with poor survival in ovarian carcinoma. Cancer 110: 1264-1271, 2007.

69. Corin I, Di Giacomo MC, Lastella P, Bagnulo R, Guanti G and Simone C: Tumor-specific hyperactive low-molecular-weight cyclin $\mathrm{E}$ isoforms detection and characterization in non-metastatic colorectal tumors. Cancer Biol Ther 5: 198-203, 2006.

70. Akli S, Zheng PJ, Multani AS, et al: Tumor-specific low molecular weight forms of cyclin $\mathrm{E}$ induce genomic instability and resistance to p21, p27, and antiestrogens in breast cancer. Cancer Res 64: 3198-3208, 2004.

71. Wingate H, Bedrosian I, Akli S and Keyomarsi K: The low molecular weight (LMW) isoforms of cyclin $\mathrm{E}$ deregulate the cell cycle of mammary epithelial cells. Cell Cycle 2: 461-466, 2003.

72. Akli S, Van Pelt CS, Bui T, et al: Overexpression of the low molecular weight cyclin $\mathrm{E}$ in transgenic mice induces metastatic mammary carcinomas through the disruption of the ARF-p53 pathway. Cancer Res 67: 7212-7222, 2007.

73. Sozmen M, Tunca R and Dag Erginsoy S: Cyclin A expression is associated with apoptosis and mitosis in murine 3-methylcholanthrene-induced fibrosarcomas. Exp Toxicol Pathol 61: 41-49, 2009.

74. Welm AL, Timchenko NA, Ono Y, et al: C/EBPalpha is required for proteolytic cleavage of cyclin A by calpain 3 in myeloid precursor cells. J Biol Chem 277: 33848-33856, 2002.

75. Church SL, Grant JW, Ridnour LA, et al: Increased manganese superoxide dismutase expression suppresses the malignant phenotype of human melanoma cells. Proc Natl Acad Sci USA 90: 3113-3117, 1993

76. Li JJ, Oberley LW, St Clair DK, Ridnour LA and Oberley TD: Phenotypic changes induced in human breast cancer cells by overexpression of manganese-containing superoxide dismutase. Oncogene 10: 1989-2000, 1995.

77. Yan T, Oberley LW, Zhong W and St Clair DK: Manganesecontaining superoxide dismutase overexpression causes phenotypic reversion in SV40-transformed human lung fibroblasts. Cancer Res 56: 2864-2871, 1996.

78. Waldman T, Zhang Y, Dillehay L, et al: Cell-cycle arrest versus cell death in cancer therapy. Nat Med 3: 1034-1036, 1997.

79. O'Connor PM and Fan S: DNA damage checkpoints: implications for cancer therapy. Prog Cell Cycle Res 2: 165-173, 1996. 